\title{
Types and abundance of macro- and micro-marine debris at Sebatik Island, Tawau, Sabah
}

\author{
Abentin Estim* and Rafidah Sudirman \\ Borneo Marine Research Institute, Universiti Malaysia Sabah, 88400 Kota Kinabalu, Sabah, Malaysia \\ *Corresponding author: abentinestim@gmail.com
}

\begin{abstract}
The amount of marine debris is increasing worldwide and has become a matter of serious concern. It is important to identify the nature of debris to understand the sources and to devise practically feasible methods for managing this problem. This study was carried out at Sebatik Island on the east coast of Sabah with the aim of examining the types and abundance of macro - and micro-debris. The observations covered a period of December 2015 - May 2016. Debris collected from different stations was compared. Transect line method was used to assess the stranded macro-marine debris (SMD). Evaluation of floating macrodebris (FMD) was done by surveys of the selected areas. Density separation technique was applied in order to extract the micro marine debris (MMD). Results showed 14 types of SMD and 9 types of FMD in the study areas. Three major types of SMD and FMD were discarded plastic, organic debris and plastic bottles. Four types of MMD recorded at the beach and mudflat areas were fragments, fiber, films and polystyrene. Based on the comparison between stations (S), S2 showed the highest abundance

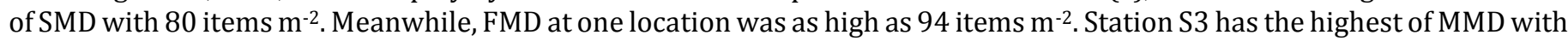
22 items $\mathrm{ml}^{-1}$. Plastic formed (40\%) of the SMD category whereas FMD constituted $42 \%$ at the Sebatik Island. Small fragments and film were the most abundant of MMD (32\%). This study highlights the scale of the marine debris problem in Sebatik Island and calls for a comprehensive plan of action to protect the Island's marine ecosystem services.
\end{abstract}

Keywords: Pollution, Marine debris, Sebatik Island, Tawau

\section{Introduction}

Marine debris is considered as an increasingly serious problem of pollution of the oceans. There is still no effective solution to get rid of it, most of which is not biodegradable. It remains in the sea for long and accumulates to enormous volumes. Marine debris includes any form of manufactured or processed material discarded, disposed or abandoned that enters the marine environment either intentionally or unintentionally, or drained to the sea through rivers, runoff, and sewage system or even deposited by the wind (Galgani et al., 2010). The main source of marine debris is anthropogenic activity such as deliberate dumping of trash and improper waste disposal.

Macro debris is defined as any dense material that is manufactured and disposed into the marine environment mostly by human activities (Lippiat et al., 2012). According to the Environmental Protection Agency, EPA (2011), macro debris may consist of plastic, metals, styrofoam, rubber and derelict fishing gear. Shore litter might also have hazardous materials like knife, glass, scissors and syringe. The shore litter causes habitat degradation and is hazardous for marine animals (UNEP, 2009).

Micro debris consists of micro plastic or elements of $<1 \mathrm{~mm}$ to $5 \mathrm{~mm}$ size (Imhof et al., 2012). The typical micro debris comprises small fragments of products such as film or sheet, fiber and expanded polystyrene (EPS) that pile up over time. There are two sources of micro plastic, namely primary and secondary (Cole et al., 2011). The former are the micro-sized products, for example, beads in the exfoliating gel, while the latter are micro fragments originating from macro plastic products. Both these categories of marine debris can be found scattered at the seafront, floating in the sea water or settled at the sea bottom. Macro debris is conspicuous enough to be visible to the naked eye but micro debris comprises tiny particles that are not so easily noticed as individual fragments, requiring multiple attempts for sampling.

Marine debris poses great threat to our ocean ecosystem. UNEP (2009) has documented the marine debris as an immense threat that is growing by the day, especially in the marine coastal environment. It also considered a global problem, contributed by all countries worldwide and should be addressed urgently. Marine debris affects human beings directly or indirectly, and has serious implications for marine life. Instances of marine wildlife suffering death due to marine debris are often reported from around the world, including from Malaysia. For example, on 19 May 2015, a dolphin was found stranded at the Likas Bay of Kota Kinabalu. It died 7 days later and the post-mortem examination revealed the cause of death was marine debris. Stomach of this specimen contained 44 pieces of plastic weighing $4.25 \mathrm{~kg}$ (Sario, 2015) as widely reported by media of mass communication for public awareness. 
While the impact of macro debris on marine organisms is widely reported the effect of micro debris is poorly understood. Micro debris by virtue of its small particle size is ingested by low trophic fauna (Wright, 2013) and this affects all the trophic levels. Browne et al. (2008) have documented the ingestion of micro plastic by blue mussel, Mytilus edulis. However, little work has been done on how exactly it affects the species feeding in low levels of food chain (filter feeders or deposit feeders) and full extent of the ecological problem that it creates.

This study was designed to present information on the problem of marine debris in Sebatik Island in Tawau, on the east coast of Sabah. The findings will provide muchneeded evidence that can be used to understand the problem in a broader context for possible measures aimed at protecting the marine ecosystem of Sabah. From cultural, traditional and economic perspectives, the marine ecosystem services have played a vital role in Sabah. Marine debris problem is undermining these services and, therefore, remedial measures should be taken through policy initiatives for effective solid waste management.

\section{Methodology}

\section{Study sites}

Sebatik Island is located on the east coast of Borneo and is shared by Malaysia and Indonesia. Total area of the island is $452.2 \mathrm{~km}^{2}$, of which $204.7 \mathrm{~km}^{2}$ belongs to Malaysia, with the geographical coordinates: $4.1672^{\circ} \mathrm{N}, 117.7839^{\circ} \mathrm{E}$. The island has a flat coastal topography. The estimated coastal length of Sebatik Island is $48 \mathrm{~km}$ (Google Earth). Located on its northern part is the ecologically sensitive Cowie Bay, just 8 $\mathrm{km}$ from Tawau mainland. It takes about 20 minutes by boat from Tawau to Kampung Sungai Tongkang Jetty in Sebatik. Malaysian territory in the Sebatik Island is home to some 25,000 people. There is a rich growth of mangroves along the coastline.

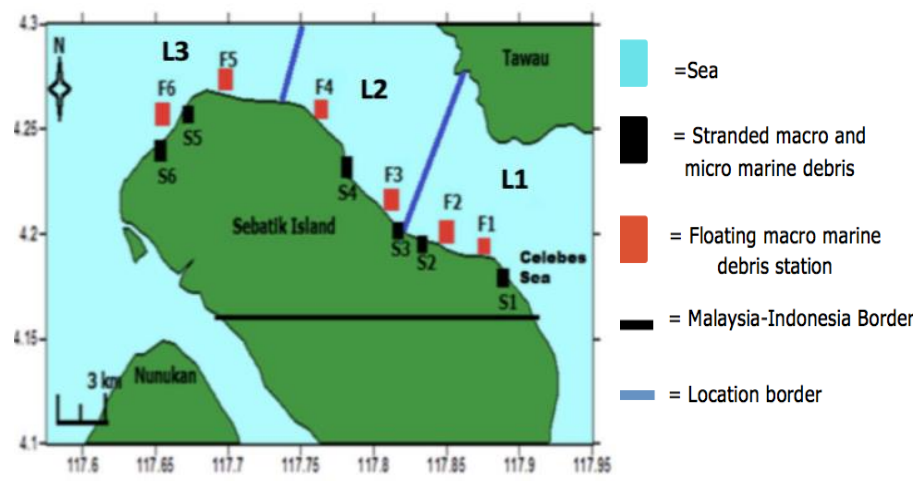

Figure 1. Sampling stations at the three locations (L1, L2 and L3) of Sebatik Island. The stranded micro and macro marine debris were collected at stations S1 - S6 and the floating marine debris was sampled at F1 to F6

\section{Sampling stations}

Six stations (Figure 1) of Sebatik Island were chosen for sampling of micro marine debris (MMD) and stranded macro marine debris (SMD). The floating macro debris (FMD) was surveyed at the coastal area of Sebatik Island at three locations (L1, L2, and L3). Each of these locations has two stations. Their coordinates are shown in Table 1. There is a rich growth of mangroves along the coastline of Sebatik Island, leaving only one beach area which was selected as station 1 (S1). Other stations were mudflat areas (S2, S3, S4, S5 and S6). The sampling stations were chosen for stranded macro debris based on length of the beach. Field samplings were done twice during December 2015 and early Mac 2016.

Table 1. Coordinates of the selected sampling stations for micro marine debris (MMD), stranded macro debris (SMD) and floating marine debris (FMD) at the Sebatik Island

\begin{tabular}{|c|c|c|c|}
\hline \multirow[t]{2}{*}{ Station } & \multicolumn{2}{|c|}{ Coordinate } & $\begin{array}{l}\text { Length of beach/ } \\
\text { mudflats }(\mathrm{m})\end{array}$ \\
\hline & Longitude & Latitude & \\
\hline S1- Sungai Melayu area & $4.182443^{\circ}$ & $117.884191^{\circ}$ & 783 \\
\hline F1- & $4.190425^{\circ}$ & $117.878017^{\circ}$ & \\
\hline S2- Less human population/unpopulated & $4.198082^{\circ}$ & $117.820200^{\circ}$ & 1772 \\
\hline F2- & $4.198404^{\circ}$ & $117.847775^{\circ}$ & \\
\hline S3- Sungai Tongkang village area & $4.212581^{\circ}$ & $117.801521^{\circ}$ & 779 \\
\hline F3- & $4.217789^{\circ}$ & $117.796410^{\circ}$ & \\
\hline S4- Less human population/unpopulated & $4.229724^{\circ}$ & $117.778795^{\circ}$ & 821 \\
\hline F4 & $4.255205^{\circ}$ & $117.757203^{\circ}$ & \\
\hline S5- Mentadak village area & $4.254427^{\circ}$ & $117.665153^{\circ}$ & 860 \\
\hline F5 & $4.270989^{\circ}$ & $117.713044^{\circ}$ & \\
\hline S6- Wallace Bay village area & $4.142192^{\circ}$ & $117.39002^{\circ}$ & 395 \\
\hline F6 & $4.269802^{\circ}$ & $117.664921^{\circ}$ & \\
\hline
\end{tabular}

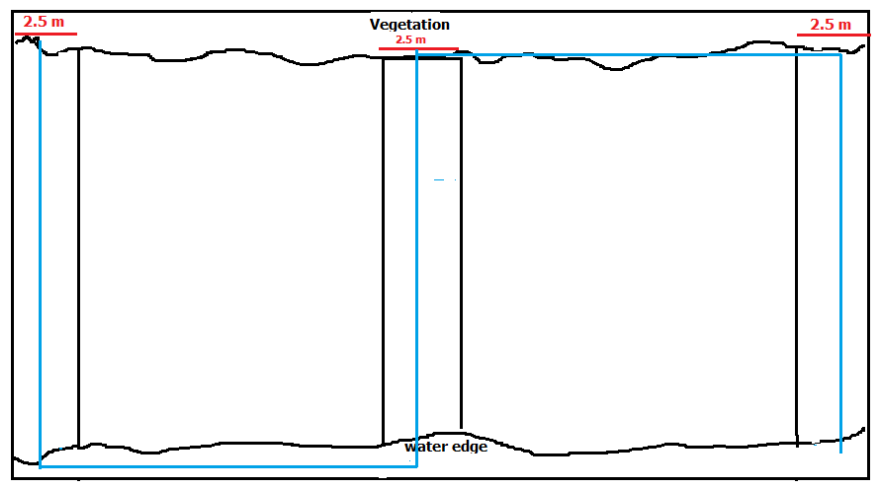

Figure 2. Line transect method used for assessing the types and abundance of stranded macro marine debris. The blue line indicates the walking path for the observer

\section{SMD samplings}

Line transect method modified from Velander and Mocogni (1999) was used in assessing the type and abundance of stranded macro marine debris (Figure 2). A transect of $50 \mathrm{~m}$ was laid and divided into three parts. Each part was marked, and $2.5 \mathrm{~m}$ gap drawn at the particular angle. Purpose of $2.5 \mathrm{~m}$ gap was to use it as a walking path for the observer to avoid bias during the assessment. SMD measurement was carried out as the observer walked in a zig-zag way which was considered necessary in order to avoid bias in measurement, and to ensure that all the SMD was counted. SMD were categorized and recorded in the survey sheets.

The survey sheet included several sets of data categories such as sampling date, description of sampling station, type of beach or coastal area, coordinates, distance between coastal vegetation and water edge and types of 
stranded macro debris. Data pertaining to marine debris was expressed as the number $\mathrm{m}^{-2}$ as shown in Equation 1.

$\mathrm{D}=\mathrm{n}(\mathrm{mv} \times \mathrm{mt})^{-1}$ Equation 1

$D=$ items $\mathrm{m}^{-2}$

$\mathrm{n}=$ macro debris items

$\mathrm{mv}=$ the length of vegetation line

$\mathrm{mt}=$ the length of transect $(50 \mathrm{~m})$

Comparison between sampling stations was done using the ANOVA test for five stations (S2, S3, S4, S5, and S6); S1 was the only beach while the remaining areas were mudflat habitats.

\section{FMD samplings}

FMD was surveyed using a boat navigated at a speed of $4-10$ knots. Once FMD was seen on the surface of sea, the coordinates of the places where FMD occurred were recorded. FMD was classified as stated on the survey sheet. Spatial coverage of FMD was measured by starting point and end point (Figure 3). The boat then moved perpendicular to the end, either upwards or backwards, depending on how the FMD was scattered in the sea. In order to measure the length and width of FMD, the distance between the coordinates was measured using Google Earth map. The data was presented as $F M D=$ debris $\mathrm{m}^{-2}$ and as gross total evaluated using Equation 2 (modified from Thiel et al., 2003).

$\mathrm{FMD}=\mathrm{n}(\mathrm{l} \times \mathrm{W})^{-1}$ Equation 2

FMD = Floating macro debris

$\mathrm{n}=$ number of items

$l=$ length between starting point and end point $(\mathrm{km})$ $\mathrm{w}=$ length from the end point to the widest point $(\mathrm{km})$
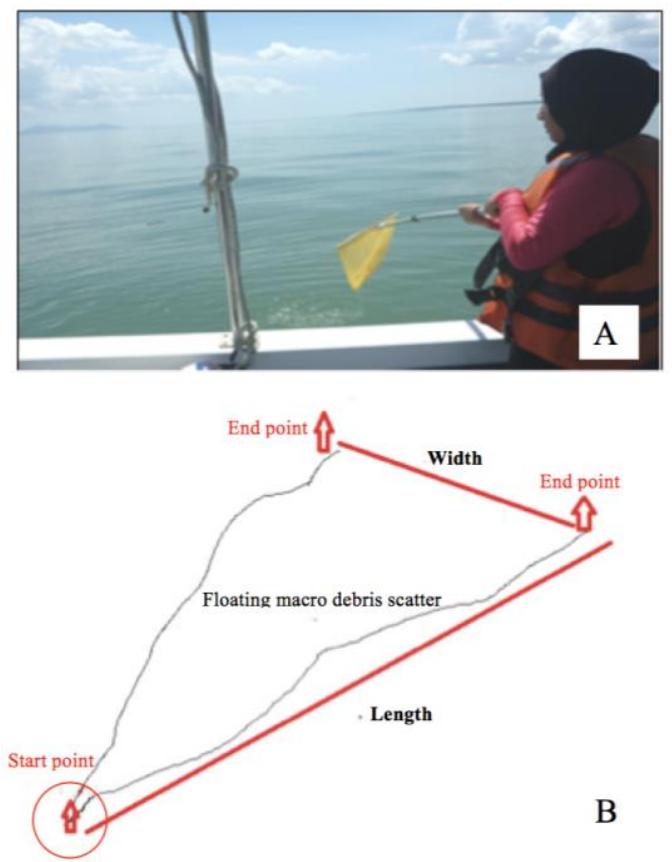

Figure 3. Floating macro debris was collected using a handnet operated from a boat with the speed of $4-10$ knots (A). Surveyed areas were estimated using Google Earth map from the coordinates, which were recorded during sampling (B)

\section{Samplings}

Sediment samples were taken in order to assess the type and abundance of MMD. Technique for MMD field samplings and laboratory analyses were modified from Song et al. (2015). Five scoops of sediment samples were randomly collected at $5 \mathrm{~cm}$ depth of $0.5 \mathrm{~m} \times 0.5 \mathrm{~m}$ quadrate. The sediment samples were sieved using $1 \mathrm{~mm}$ mesh size and placed in a tray. All the five scoops of sediments were then mixed to form a composite sediment sample and kept in $1.0 \mathrm{~L}$ polyethylene bottle. The sediment samples were brought to laboratory for further analysis. Samples that were wet were air dried before sieving. The composite sediment sample weighing $50 \mathrm{~g}$ was taken, mixed with $150 \mathrm{ml}$ Nacl solution, allowed to stand undisturbed for 10 minutes before vigorously shaking. The supernatant was collected in $100 \mathrm{ml}$ beakers and stored for 24 hours. Subsequently, all samples were filtered using membrane filter of the size $47 \mathrm{~mm}$ and then dried in an oven for 3 hours at $60^{\circ} \mathrm{C}$. Observations on the types of micro debris were made using stereomicroscope. Equation 3 was followed for calculation of the number of micro debris $\mathrm{ml}^{-1}$ (Song et al., 2015).

$\mathrm{N}=\mathrm{n} \mathrm{m}^{-1}$ Equation 3

$\mathrm{N}=$ number of micro debris particles

$\mathrm{n}=$ micro debris items

$\mathrm{m}=$ volume of supernatant $(\mathrm{ml})$

\section{Results}

\section{Types and abundance of SMD at Sebatik Island}

Results showed that 14 types of SMD were found at the beach and mudflat areas of Sebatik Island (Figure 4). The top three SMD items were plastic (40\%) including food wrappers and plastic bags, organic debris (30\%) such as coconut husk, woods and dried palm, and plastic bottles ( 8 $\%)$. The others were styrofoam, lid and bottle caps, aluminum, shoe or footwear, cloth, glass, paper, metal, ropes and other types such as odd items, refrigerator door and baby diapers (Photo 1).

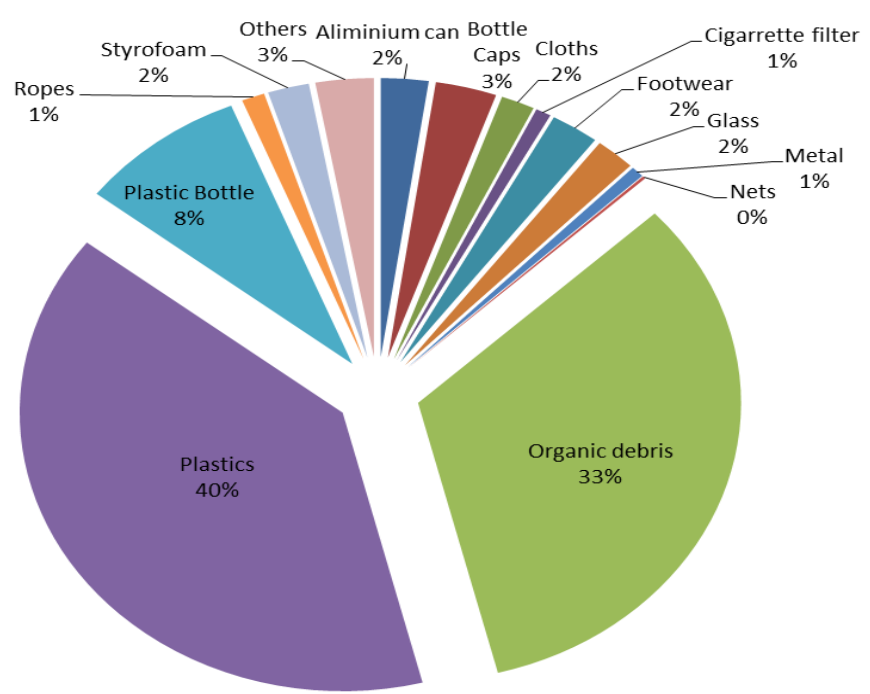

Figure 4. Percentages of 14 types of stranded macromarine debris encountered at the beach and mudflat areas of Sebatik Island 

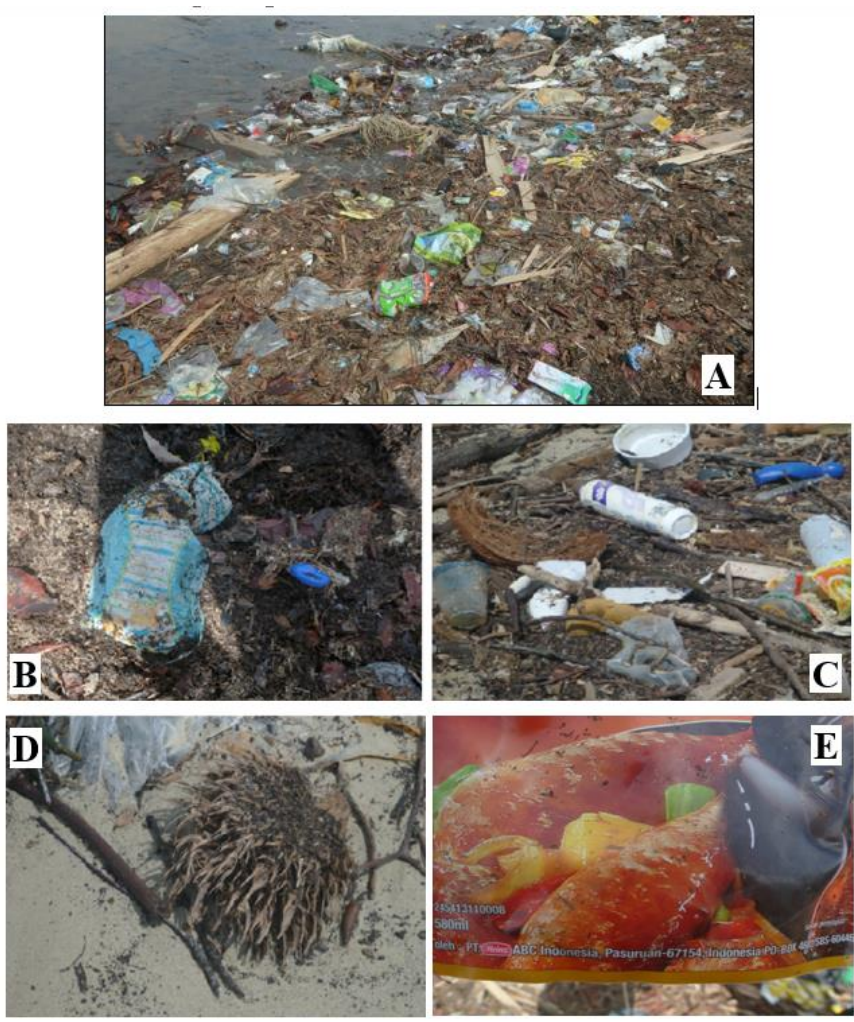

Photo 1. Stranded macro-marine debris (SMD) observed at the station S1 during the survey in December 2015. Some of the debris included plastics (A), baby diaper (B), coconut husk and dried palm (D) and SMD label from Indonesia (E)

Details of the types and abundance of SMD at the six stations of Sebatik Island are shown in Table 2 and Figures 4 and 5. Evidently, the highest SMD type recorded at the S1 was plastic material $\left(515.0 \pm 106.0\right.$ items per $\left.\mathrm{m}^{2}\right)$ and the lowest was net $\left(2.0 \pm 2.8\right.$ items per $\left.\mathrm{m}^{2}\right)$. At S2, S3, S4, S5 and S6 stations, the highest SMD type was organic debris. The recorded values were $37.0 \pm 2.8$ items $\mathrm{m}^{-2}$ at $\mathrm{S} 2,22.5 \pm 3.5$ items $\mathrm{m}^{-2}$ at S3, $28.0 \pm 1.4$ items $\mathrm{m}^{-2}$ at S4, $25.5 \pm 3.5$ items $\mathrm{m}^{-}$ 2 at S5 and $24.0 \pm 0.0$ items $\mathrm{m}^{-2}$ at S6. The lowest SMD type at

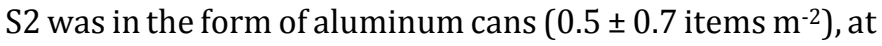
S3 and S5 were bottle caps, respectively $1.5 \pm 2.1{\text { items } \mathrm{m}^{-2}}^{-2}$ and $1.0 \pm 1.4$ items $\mathrm{m}^{-2}$, at S4 was metal $\left(1.0 \pm 1.4\right.$ items $\left.\mathrm{m}^{-2}\right)$ and at S6 were nets and others $\left(1.0 \pm 1.4\right.$ items $\left.\mathrm{m}^{-2}\right)$. Comparison of types and abundance of SMD at the five mudflat stations of the Island is given in Figure 4. One-way ANOVA analysis did not show any significant difference (P>0.05) in SMD abundance among the six stations, except for the footwear $(\mathrm{F}=15.0, \mathrm{p}=0.005)$ and organic debris $(\mathrm{F}=$ 9.4, $\mathrm{p}=0.015$ ).

\section{Types and abundance of FMD at Sebatik Island}

Nine major types of FMD namely, bottle caps, cigarette filter, footwear, organic debris, plastic materials, plastic bottles, ropes, styrofoam and others were encountered in the coastal water of Sebatik Island (Table 3). The highest amount of FMD was that of discarded plastic (41.7\%), followed by plastic bottles (20.2\%), organic debris (14.1\%) and styrofoam (12.0\%) as shown in Figure 6. Plastic material

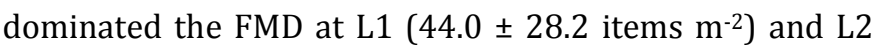
$\left(21.5 \pm 21.9\right.$ items $\left.\mathrm{m}^{-2}\right)$, while at $\mathrm{L} 3$, the organic debris constituted the largest $\left(22.0 \pm 5.6\right.$ items $\left.\mathrm{m}^{-2}\right)$ proportion. One-way ANOVA analysis revealed no significant difference $(\mathrm{P}<0.05)$ in FMD types among the locations.

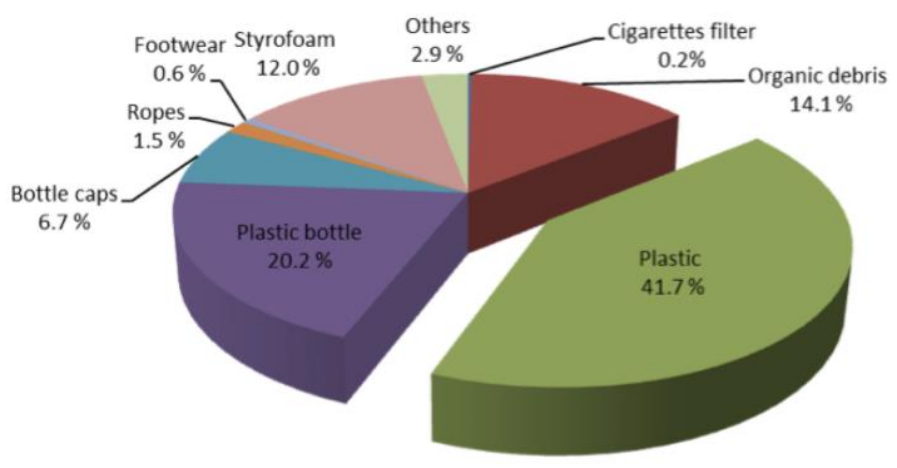

Figure 6. Percentage of nine types of floating macro marine debris recorded at the coastal areas of Sebatik Island.

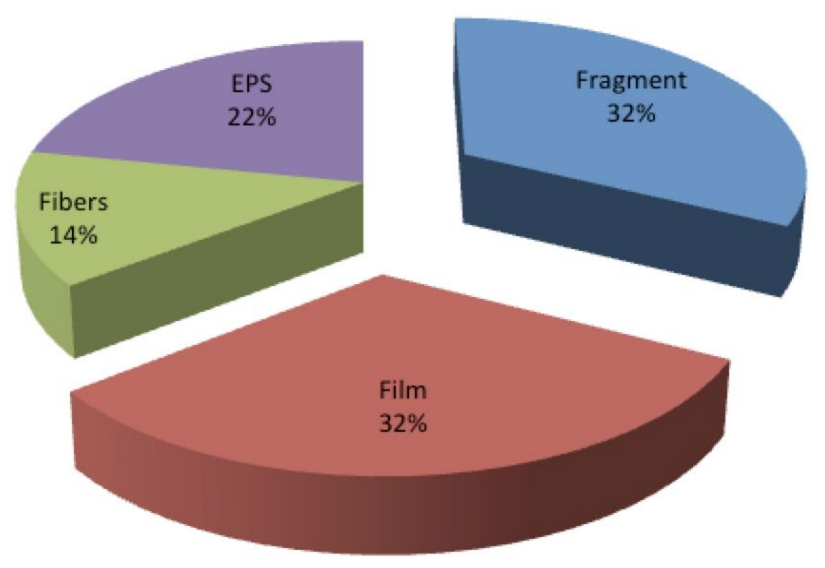

Figure 7. Percentage of four types of micro-marine debris found at the Sebatik Island.

Types and abundance of MMD at Sebatik Island

Results indicate four MMD types at the beach and mudflat areas of Sebatik Island, namely, fragments, fiber, film and EPS. The highest MMD components recorded were fragment from film (32\%), followed by EPS (22\%) and the lowest was fiber $(14 \%)$ as shown in Figure 7.

Types and abundance of MMD in the sediment from six stations are shown in Table 4. The highest proportion of MMD recorded at $\mathrm{S} 1$ was in the form of fragments of films $\left(15.0 \pm 4.2\right.$ items $\left.\mathrm{ml}^{-1}\right)$, at S2, S4 and S6. The quantity was 7.0 \pm 5.6 items ml-1, $7.5 \pm 3.5$ items ml-1 and $8.0 \pm 8.4$ items ml-1, while at S3 and S5 the debris was EPS in abundance of $7.5 \pm$ 7.7 items $\mathrm{ml}^{-1}$ and $6.5 \pm 4.9$ items $\mathrm{ml}^{-1}$. One-way ANOVA analysis showed no significant difference $(\mathrm{P}<0.05)$ in MMD types among the stations. 


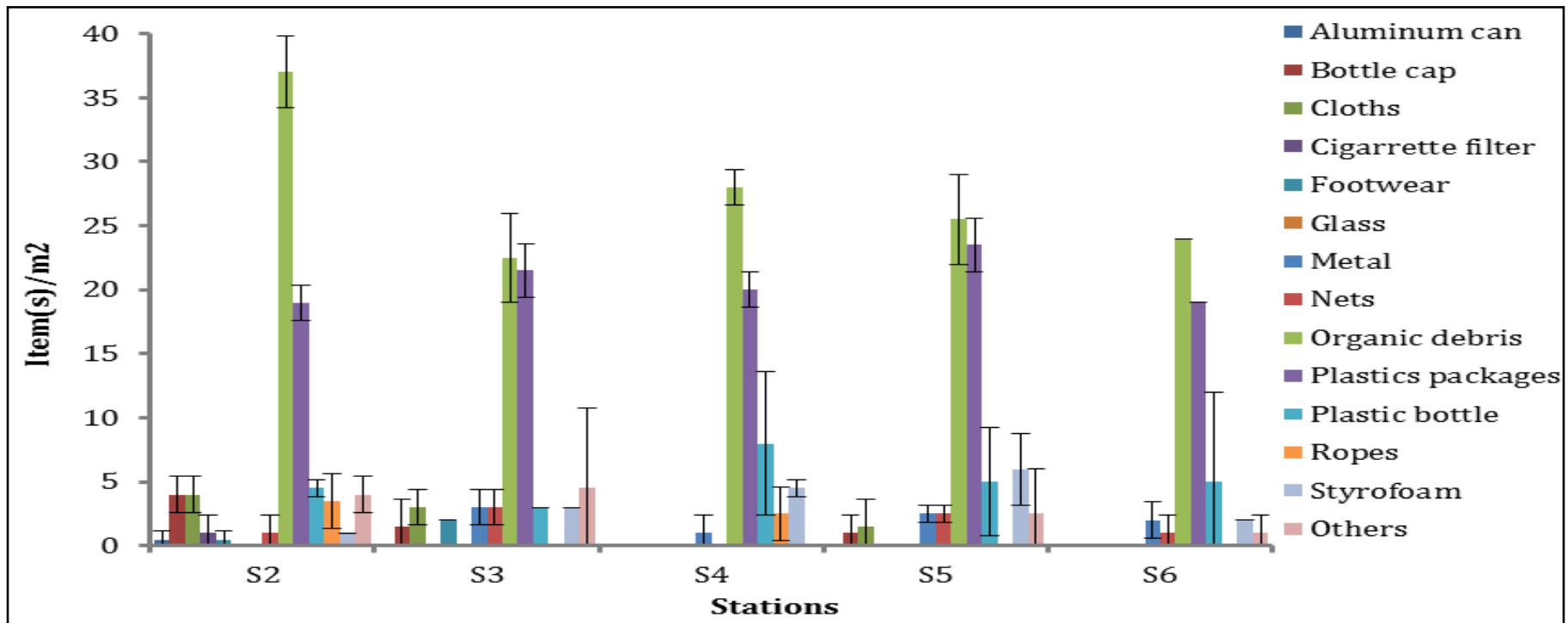

Figure 5. Types and abundance of stranded macro-marine debris (SMD) at the five stations in the mudflat areas of Sebatik Island

Table 2. Types and abundance of stranded macro-marine debris found at six stations of Sebatik Island. Data is presented as means $\left( \pm\right.$ S.D) items $\mathrm{m}^{-2}$

\begin{tabular}{|c|c|c|c|c|c|c|c|}
\hline Station & $\mathrm{S} 1$ & $\mathrm{~S} 2$ & S3 & S4 & S5 & S6 & $\begin{array}{c}\text { Mean Total ( } \pm \\
\text { SD) }\end{array}$ \\
\hline Aliminium can & $31.0 \pm 5.6$ & $0.5 \pm 0.7$ & - & - & - & - & $5.2 \pm 12.1$ \\
\hline Bottle Caps & $40.0 \pm 22.6$ & $4.0 \pm 1.4$ & $1.5 \pm 2.1$ & - & $1.0 \pm 1.4$ & - & $7.7 \pm 16.6$ \\
\hline Cloths & $22.0 \pm 7.0$ & $4.0 \pm 1.4$ & $3.0 \pm 1.4$ & - & $1.5 \pm 2.1$ & - & $5.0 \pm 8.7$ \\
\hline Cigarrette filter & $10.0 \pm 7.0$ & $1.0 \pm 1.4$ & - & - & - & - & $1.8 \pm 4.4$ \\
\hline Footwear & $31.5 \pm 34.6$ & $0.5 \pm 0.7$ & $2.0 \pm 0.0$ & - & - & - & $5.6 \pm 15.9$ \\
\hline Glass & $26.0 \pm 1.4$ & - & - & - & - & - & $4.3 \pm 9.9$ \\
\hline Metal & $8.5 \pm 0.7$ & - & $3.0 \pm 1.4$ & $1.0 \pm 1.4$ & $2.5 \pm 0.7$ & $2.0 \pm 1.4$ & $2.8 \pm 2.9$ \\
\hline Nets & $2.0 \pm 2.8$ & $1.0 \pm 1.4$ & $3.0 \pm 1.4$ & - & $2.5 \pm 0.7$ & $1.0 \pm 1.4$ & $1.5 \pm 1.5$ \\
\hline Organic debris & $430.0 \pm 84.8$ & $37.0 \pm 2.8$ & $22.5 \pm 3.5$ & $28.0 \pm 1.4$ & $25.5 \pm 3.5$ & $24.0 \pm 0.0$ & $94.5 \pm 158.8$ \\
\hline Plastics Packages & $\begin{array}{l}515.0 \\
106.0\end{array} \quad \pm$ & $19.0 \pm 1.4$ & $21.5 \pm 2.1$ & $20.0 \pm 1.4$ & $23.5 \pm 2.1$ & $19.0 \pm 0.0$ & $103.0 \pm 195.0$ \\
\hline Plastic Bottle & $110.0 \pm 28.2$ & $4.5 \pm 0.7$ & $3.0 \pm 0.0$ & $8.0 \pm 5.6$ & $5.0 \pm 4.2$ & $5.0 \pm 7.0$ & $22.5 \pm 41.8$ \\
\hline Ropes & $15 \pm 2.8$ & $3.5 \pm 2.1$ & - & $2.5 \pm 2.1$ & - & - & $3.5 \pm 5.6$ \\
\hline $\begin{array}{l}\text { Styrofoam } \\
\text { Others (toothbrush, } \\
\text { baby diapers, gas }\end{array}$ & $27.0 \pm 0.0$ & $1 \pm 0.0$ & $3.0 \pm 0.0$ & $4.5 \pm 0.7$ & $6.0 \pm 2.8$ & $2.0 \pm 0.0$ & $7.2 \pm 9.4$ \\
\hline $\begin{array}{l}\text { catridge, door of } \\
\text { refrigerator, canvas, } \\
\text { toy) }\end{array}$ & $38.0 \pm 16.9$ & $4 \pm 1.4$ & $4.5 \pm 6.3$ & - & $2.5 \pm 3.5$ & $1.0 \pm 1.4$ & $8.3 \pm 15.0$ \\
\hline Total & $1306.0 \pm 22.8$ & $80.0 \pm 20.30$ & $64.0 \pm 18.2$ & $64.0 \pm 13.6$ & $70.0 \pm 21.0$ & $54.0 \pm 11.2$ & \\
\hline
\end{tabular}

Table 3. Types and abundance of floating macro-marine debris at three locations. Data is presented as means ( \pm S.D) items per $\mathrm{m}^{2}$

\begin{tabular}{lcccc}
\hline Location & $\mathbf{1}$ & $\mathbf{2}$ & $\mathbf{3}$ & \\
\hline Item(s) per $\mathbf{~ m}^{\mathbf{2}}$ & & & & Total \\
\hline Bottle caps & $7.0 \pm 0.0$ & $2.5 \pm 3.5$ & $2.5 \pm 2.1$ & $4.0 \pm 2.9$ \\
Cigarette filter & - & $0.5 \pm 0.7$ & - & $0.1 \pm 0.4$ \\
Footwear & $1.0 \pm 0.0$ & - & - & $0.1 \pm 0.4$ \\
Organic debris & $14.0 \pm 9.8$ & $10.5 \pm 2.1$ & $22.0 \pm 5.6$ & $15.5 \pm 7.3$ \\
Plastic materials & $44.0 \pm 28.2$ & $21.5 \pm 21.9$ & $8.0 \pm 5.6$ & $24.5 \pm 22.9$ \\
Plastic bottle & $15.0 \pm 0.0$ & $21.5 \pm 21.9$ & $8.0 \pm 5.6$ & $14.8 \pm 11.7$ \\
Rope & $0.5 \pm 0.7$ & $0.5 \pm 0.7$ & $0.5 \pm 0.7$ & $0.5 \pm 0.5$ \\
Styrofoam & $10.0 \pm 1.4$ & $16.0 \pm 9.8$ & $4.5 \pm 0.7$ & $10.0 \pm 6.8$ \\
Others (baby diapers, toothbrush, gallon) & $2.5 \pm 3.5$ & $2.5 \pm 0.7$ & $0.5 \pm 0.7$ & $1.8 \pm 1.9$ \\
\hline Total & $94.0 \pm 44.2$ & $75.5 \pm 61.30$ & $46.0 \pm 15.4$ & \\
\hline
\end{tabular}


Table 4. Types and abundance of micro marine debris found in sediment of six stations at Sebatik Island, Sabah. Data is presented as mean $\left( \pm\right.$ S.D) of items $\mathrm{ml}^{-1}$

\begin{tabular}{|c|c|c|c|c|c|c|c|}
\hline Station & S1 & S2 & S3 & S4 & S5 & S6 & Total \\
\hline Fragment (items $\mathrm{ml}^{-1}$ ) & $15.0 \pm 4.2$ & $7.0 \pm 1.4$ & $5.0 \pm 1.4$ & $2.5 \pm 0.7$ & $4.5 \pm 2.1$ & $4.0 \pm 4.2$ & $6.3 \pm 4.7$ \\
\hline Film (items $\mathrm{ml}^{-1}$ ) & $7.0 \pm 1.4$ & $7.0 \pm 5.6$ & $4.5 \pm 0.7$ & $7.5 \pm 3.5$ & $3.5 \pm 2.1$ & $8.0 \pm 8.4$ & $6.2 \pm 3.7$ \\
\hline Fibers (items $\mathrm{ml}^{-1}$ ) & $5.5 \pm 4.9$ & $1.0 \pm 0.0$ & $5.0 \pm 1.4$ & $0.5 \pm 0.7$ & $2.5 \pm 2.1$ & $1.5 \pm 0.7$ & $2.6 \pm 2.6$ \\
\hline EPS (items $\mathrm{ml}^{-1}$ ) & $4.5 \pm 0.7$ & $0.5 \pm 0.7$ & $7.5 \pm 7.7$ & $3.0 \pm 0.0$ & $6.5 \pm 4.9$ & $3.5 \pm 0.7$ & $4.2 \pm 3.6$ \\
\hline Total & $32.0 \pm 11.2$ & $15.5 \pm 7.7$ & $22.0 \pm 11.2$ & $14.0 \pm 4.9$ & $17.0 \pm 11.2$ & $17.0 \pm 14.0$ & \\
\hline
\end{tabular}

\section{Discussion}

\section{Types and abundances of SMD and FMD}

Despite important marine ecosystem services provided by Sebatik Island, the increasing amounts of marine debris resulting from anthropogenic activities have caused environmental degradation. If unchecked, this will further undermine the marine life that the Island supports and curtail the resources that have traditionally benefitted the society. Presence of 14 types of SMD in a density of 1644 items $\mathrm{m}^{-2}$ at the beach and mudflat areas reflects the extent of the problem of waste disposal. It is important to note that items including plastic waste, organic debris and discarded plastic bottles were the dominant types of litter (Figure 4). There is a great deal of spatial variation in the nature and amount of debris, depending on many factors such as the population density, habits of the people, use of the area (housing, business, recreation) and socio-economic profile of the community. Estim et al. (2014) during survey of three beaches (Tanjung Aru, Likas and Sepanggar at the seafront Universiti Malaysia Sabah, ODEC-UMS) in the capital Kota Kinabalu reported 9 types of SMD, the major ones being the plastic bottles, plastic packages and Styrofoam. In Mantanani Island of Kota Belud, Estim and Sidin (2015) reported that plastic beverage bottles/caps and cups made of polystyrene and foamed plastic were quite abundant. They observed 26,570 debris items at the beaches of Mantanani Island, with 19 SMD types. In Malaysia, Agamuthu (2012) recorded plastic waste as the most abundant type of marine debris item in all the beaches surveyed in Peninsular Malaysia, with the presence of plastic bags, bottles, and food wrappers contributing $36-94 \%$ of all the debris. In many other countries, also the plastic debris formed a significant part of the marine debris (Bravo et al., 2009). Generally, the scenario is largely determined by the high buoyancy and long-life expectancy of hard plastics in marine environment (Andrady, 1990). In addition, many marine debris items, particularly those heavier in density (for example, metal, glass) compared to plastic get settled at the seabed (Beck and Barros, 1991) and their accumulated amounts can be quite high.

The proportion of FMD in the surface water of Sebatik Island was the dominant type, with $41.7 \%$ of plastic (Figure 6). This is comparable to the amount reported by Dixon and Dixon (1983) in North Sea. Derraik (2002) attributed it to increased use of plastics in the past few decades and properties of the plastic material- light weight and long-term persistence in the ocean. Plastic has become ubiquitous and forms sometimes up to $95 \%$ of the waste that accumulates at the shore, sea surface and seafloor (Galgani et al., 2015).

It is difficult to know how much amount of marine debris is brought to Sebatik Island by ocean currents and the quantity deposited by wind action. Evidently, the macro marine debris here comes from the inhabitants of Sebatik Island. It could be from waste originating from the Island as well as from the mainland Tawau. Some of the macro debris may also originate from Indonesia based on the details from the macro marine debris (Photo 1). Several factors influence the accumulation of debris in the coastal areas. These include shape of the beach, location of the area and nature of debris (Turra et al., 2014). Plastic pieces and particles, plastic bottles, styrofoam and some organic debris are floatable and thus easily drift with the ocean currents (Vianello et al., 2013). They may originate from elsewhere and deposited in the marine area around Sebatik Island.

Based on the present observations, quantities of discarded footwear and organic debris were significantly different among the five stations in the stranded macro marine debris category. Wood may come from the vegetation that grows nearby and drifted by the ocean currents. Same may be true for some other items as well, especially discarded products of personal use.

\section{Types and abundance of MMD at Sebatik Island}

Occurrence of large quantities of MMD, especially tiny fragments and remains of film in Sebatik Island (32\%) owes to increasing use of the source products (nets and industrial or commercial items). It is consistent with the pattern reported from other places as well. Duhec et al. (2011) also observed fragments (43\%) formed the most abundant type of micro debris at Alphonesce, Seychelles. Similarly, Vianello et al. (2013) found as much as $86 \%$ of the waste at Venice, Italy.

The micro debris is derived from disintegration of macro debris by mechanical forces or erosion caused by chemical processes, UV light and heat (Andrady, 2011; Cole et al., 2011; Galgani et al., 2015). It varies in quantity from time to time because these factors are dynamic. Stations S1, S2 and S3 were connected to river which could transfer 
micro debris from human residential area to the coastal sediments. According to Browne et al. (2010), micro debris can enter the sediment by way of river discharge as these particles can pass through filtration system of wastewater treatment. Other than that, wind-driven currents are also known to influence micro-marine debris accumulation at beaches (Vianello et al., 2013).

\section{Adverse effects of macro- and micro-marine debris}

SMD and FMD impair the aesthetic view of the seafront, disturb the marine ecosystem and adversely affect humans directly or indirectly. SMD might consist of harmful objects such as medical waste (for example, syringe) and glass in addition to abandoned fishing gear that is reported to cause entanglement of marine wild fauna, suffocation and also drowning (Jones, 1995). When trapped in engine propeller, marine debris disrupts normal operation of boats.

Variations in size and composition of FMD increase the availability of dispersal substrata for some marine invertebrates (Winston, 1982). FMD also can facilitate transportation of some marine organisms from one place to another, often resulting in invasive non-native species establishing populations in the wild outside their normal geographical range.

Irrawaddy dolphin is frequently sighted in the Cowie Bay and the floating macro debris is hazardous for this cetacean species.

MMD is also ingested by benthic deposit feeders as well as some filter feeders in the water column, and accumulates in their gut as noticed in the case of blue mussel (Mytilus edulis) by Wright et al. (2013). This species of mussel is consumed by human beings and can pose health hazards to consumers. Through food chain the debris from low trophic level species can move to other animals and impair their health (Thompson et al., 2009). Lower trophic animals feed less selectively (Wright et al., 2013) and thus easily ingest small plastic particles.

\section{Conclusion}

Marine debris is a growing hazard worldwide. Malaysia is no exception to this problem. Quantity and composition of debris varies spatially and temporally, depending on a range of dynamic factors. Of all the debris components, proportion of plastic is higher and is causing more concern for a variety of reasons. At a time when attention is being given to harnessing benefits from the sea, the debris is reducing the potential of marine ecosystem services. This study based on observations in Sebatik Island provides evidence of causes of the debris problem and implications. It will help in sustainable management of the Island ecosystem if regular debris monitoring program is institutionalized, public awareness programs launched and regulatory mechanisms developed for Sebatik Island.

\section{Acknowledgements}

Special thanks to Universiti Malaysia Sabah for providing financial support under SBK 0193-STWN-2015 research grant. Ms. Jorinah Melson and Mr. Herman Musana, laboratory assistants, provided technical support. Students, namely Ms. Jessiane Junas and Mr. Mhamood Hassan rendered logistical assistance.

\section{References}

Agamuthu, P. \& Fauziah, S. (2012). Marine debris on selected Malaysian Beaches: Impacts of human ignorance. Proceedings of the $10^{\text {th }}$ Expert Meeting on solid waste management in Asia and Pacific Islands (SWAPI). Tottori

Andrady, A. (1990). Environmental degradation of plastics under land and marine exposure conditions. In: Proceedings of the International Conference on Marine Debris, Honolulu, 1989 (Shomura, R.S. \& Godfrey, M.L. eds). US Department of Commerce. NPAA-TM-NMFS-SWFSC 154, 848869.

Andrady, A. (2011). Microplastics in marine environment. Marine Pollution Bulletin 62,1596-1605.

Beck, C. \& Barros, N. (1991). The impact of debris on the Florida Manatee. Marine Pollution Bulletin 22, 508 - 510.

Bravo, M., Gallardo, M.A., Luna-Jorquera, G., et al. (2009). Anthropogenic debris on beaches in the SE Pacific (Chile): Results from a national survey supported by volunteers. Marine Pollution Bulletin 58, 1718-1726.

Browne M.A, Dissayanake, A., Galloway, T.S., et al. (2008). Ingested microscopic plastic translocates to the circulatory system of the mussel, Mytilus edulis (L). Environmental Science and Technology 44, 3404-3409.

Cole, M., Lindueque, P., Halsband, C., et al. (2011). Microplastics as contaminant in the marine environment: a review. Marine Pollution Bulletin 62 (12), 2588-2597.

Duhec, A.V., Jeanne, R.F., Maximenko, N., et al. (2015). Composition and potential origin of marine debris stranded in the Western Indian Ocean on remote Alphonse Island. Seychelles. Marine Pollution Bulletin 96, 76-86

Estim, A., Norinah, A. \& Mohammad, N. S. (2014). Marine Debris Pollution on the Beaches of Kota Kinabalu, Sabah. 12 ${ }^{\text {th }}$ International Borneo Research Council Conference - Diversity and Dynamism in Borneo. 5 - 7 August, Kota Kinabalu, Sabah

Estim, A. \& Sidin, M.N. (2015). Marine Debris Assessment in Mantanani island. In: Mantanani Marine Scientific Expedition 2013 (Madin, J., Saleh, E., Abd Hamid, et al. eds.) Department of Marine Park Malaysia. 47 - 63p.

Environmental Protection Agency U.S. (2011). Marine debris in North Pacific: A summary of existing information and identification data gaps. U.S EPA. 23 pp.

Galgani, F., Fleet, D., Van Franeker, J., et al. (2010). Marine Strategy Framework Directive, Task Group 10 Report: Marine Litter. In: JRC Scientific and Technical Reports (ed. N. Zampoukas). Ispra: European Commission Joint Research Centre

Imhof, H.K., Schnid, J., Nessier, R., et al. (2012). A novel, highly efficient method for the separation and quantification of plastics particles in sediment of aquatic environment. Limnological Oceanography 10, 524537.

Jones, M.M. (1995). Fishing debris in the Australian marine environment. Marine Pollution Bulletin 30, 25-33.

Lippiat, S.M., Arthur, C.d., \& Wallace, N.E., 2012. Assessing the abundance and types of marine debris on shorelines and surface waters in Chesapeake Bay tributaries stratified by land use. Presentation at the Ocean Sciences Meeting, 20-24 Feb 2012, Slat Lake City, UT, USA. Polymers 5, 118. 
Volume: 01 | December 2017, 57 - 64

Sario, R. (2015). Marine creatures most at risk. The Star Online (http://www.thestar.com.my/news/nation/2015/03/28/marine-

creatures-most-at-risk-mass-of-plastic-in-the-sea-highly-dangerous/)

Song, Y. K., Hong, S.H., Jang, M. et al. (2015). A comparison of microscope and spectroscopic in an identification method for analysis of micro plastic in environmental samples. Marine Pollution Bulletin 93, 202-209.

Thiel, M., Hinojosa, I., Vasquez, N., et al. (2003). Floating marine debris in coastal waters of the SE-Pacific (Chile). Marine Pollution Bulletin 46: 224-231.

Thompson, R.C., Moore, C.J., vom Saal, F.S., et al. (2009). Plastics, the environment and human health: current consensus and future trends. Philosophical Transactions of the Royal Society B: Biological Sciences 364 (1526), 1973-1976.

UNEP, (2009). Marine Litter: A Global Challenge. Nairobi UNEP. 232 pp.

Valender, K. \& Mocogni, M. (1999). Beach Litter Sampling Strategies Is There A Best Method? Marine Pollution Bulletin 38, 1134-1140.

Vianello, A., Boldrin. A., Guerrierro. P., et al. (2013). Microplastic particles in sediments of Lagoon of Venice, Italy: first observations on occurrence, spatial patterns and identification. Estuarine, Coastal and Shelf Science 130, 54-61.

Winston, J.E. (1982). Drift plastic-an expanding niche for a marine invertebrate? Marine Pollution Bulletin 42, 1031-1039.

Wright, S. I., Richard, C. T., Tamara, S. G. (2013). The physical impacts of microplastics on marine organism: A review. Environmental Pollution $178,483-49$. 